\title{
DEVELOPMENT OF INSTITUTIONAL PERFORMANCE: STUDY ON THE SECRETARIAT OF THE NORTHERN BORDERS REGION
}

\author{
SAAD Mohamed Ali ${ }^{1}$ \\ ${ }^{I}$ Northern Border University, Arar, (SAUDI ARABIA) \\ E-mail: masmas114@yahoo.com
}

\begin{abstract}
The study aimed to identify the impact of governance on developing institutional performance in the secretariat of the northern border region, and using the descriptive analytical approach, and collecting theoretical information from office sources, through a questionnaire distributed to 309 individual officials and employees in the secretariat of the northern border region (the main center), 238 valid questionnaires were retrieved, The Statistical Package for Social Sciences (SPSS) was used to analyze the data and test the hypotheses of the study, and the study reached several results, the most important of which is the availability of an adequate and acceptable amount of practices for the two variables of the study, in addition to the presence of a positive correlation between each of the governance with its various principles and institutional performance. The most substantial relationships between accountability were one of the principles of governance and overall institutional performance, and the lowest were the relationships between justice and equality as one of the principles of governance and overall institutional performance. Also, governance, with its various principles, explains its amount $(66.2 \%)$ of the variance in the overall institutional performance. The study recommended working on the need to pay attention to deepening the understanding and awareness of everything related to the principles and mechanisms of governance in public organizations through the continuous improvement of human resources capabilities and knowledge, as well as providing an appropriate climate for their application and increasing the level of positive impact on the various dimensions of institutional performance.
\end{abstract}

Keywords: Governance, Institutional performance, Accountability, Balanced scorecard.

JEL: M00

DOI: $10.5937 /$ intrev2102035S

UDC: $35(532)$

COBISS.SR-ID 43526409 


\section{INTRODUCTION}

Governance is one of the most critical administrative inputs in recent times due to its extreme importance in developing the organizational environment, where governance is related to administrative development mechanisms, which contributes to developing work and performance and creating a fertile environment for success and progress, Governance is a set of rules and foundations that seek to manage, direct and control operations and activities related to regulation, Given the importance of governance, and the increased interest in applying its principles its use in revealing deficiencies and weaknesses governance aims to raise the degree of awareness of decision makers, citizens, civil society and development partners in general.

Given the remarkable developments and the growing changes at the global level, most countries, especially developing ones, have sought to bring about comprehensive development by using all elements and resources of society through developing the institutional and structural performance of their public institutions by applying the principles of governance and monitoring their embodiment mechanisms and the development of services provided by public organizations is essential to raise the standard of living and achieve sustainable development. Therefore, This study attempts to identify the extent of the application of governance in the sector under study and to determine the impact of governance on institutional performance.Governance is considered one of the most essential administrative approaches that have received a great deal of attention in the recent time due to its prominent role in raising the rates of institutional performance in addition to the significant contribution to achieving sustainable development and improving the level of services provided to citizens, where governance works to enhance the concepts of integrity, transparency, participation and the rule of law, as it contributes to Effectively in the process of developing institutional performance.

The main question tackled in this study is to examine to what extent do public organizations adopt the concept of governance as an introduction to the practice of developing institutional performance by applying it to the secretariat of the Northern Border region in the Kingdom of Saudi Arabia, also the impact of the application of governance on institutional performance. This study also aims to identify the most important reasons for increasing interest in the entrance of governance as one of the most critical modern administrative approaches to improve institutional performance, and to identify the best ways to apply governance and its impact on the process of developing institutional performance, as well as present some suggestions that contribute to the proper application of governance and increase its positive impact Ali institutional performance. The importance of the study lies in highlighting the importance of applying the standards of governance and what it represents in enhancing confidence in institutional work and highlighting the importance of the work environment that is characterized by institutional governance, and its role in increasing the effectiveness of institutional performance development processes. Important in achieving sustainable development. Where it was applied to the Secretariat of the Northern Borders Region, which is a service agency that has a legal personality with financial and administrative independence affiliated with the Ministry of Municipal and Rural Affairs, and takes charge of the tasks of supervising municipal works in the region, followed by several municipalities, each municipality has a legal personality with financial and administrative independence and serves the region.

\section{THEORETICAL FRAMEWORK}

\section{GOVERNANCE}

Governance is an important concept in the regulatory environment at the level of all institutions, whether these institutions are public or private. The application of governance depends on the set of processes and procedures that achieve the desired results, and governance takes into account two parallel dimensions. The first dimension is linked to the World Bank that adopts the administrative and economic aspects of the concept, while the second dimension emphasizes the political aspect of governance that is based on the democratic values system along with reform and administrative efficiency [1].

The United Nations Development Program defines governance as, the exercise of political, economic and administrative authority to manage state affairs at all levels, through mechanisms and institutions that 
allow individuals and groups to achieve their interests, exercise their rights, fulfill their obligations and settle their differences [2]. The World Bank also defines governance as, the set of rules by which force is enforced in favor of a particular group, and therefore the government acts on behalf of individuals, and it should provide them with opportunities to participate in decision-making equally, in a framework of transparency and credibility, and even be accountable to them, which is What Makes Any Reason a Good Rule [3]. Governance means, the complex and multifaceted state of institutions, systems, structures, processes, procedures, practices, and leadership behavior in political, social, and administrative programs to achieve the aspirations of citizens"[4]. Governance also works to strike a balance between economic and social goals and individual and collective goals that aim to efficiently use resources and seek accountability for them and link the interests of individuals, institutions and society as a whole[5].

Governance supports the idea of renewing the role of the government, which is based on a set of foundations, the most important of which are working to satisfy the desires of customers, encouraging competition in providing services, attention to evaluating the performance of public organizations, forecasting problems and working to prevent them before they happen and the effectiveness of spending and achieving it for a public benefit [6]. Also, governance contributes to ensuring that efforts are focused safeguarding the higher interests of society, the state, and workers [7].There are many principles of governance issued by the United Nations Development Program, the World Bank, and the International Monetary Fund, and this study focuses on A specific set of principles issued by the United Nations Development Program to serve the objectives of the study, the following is a presentation of these principles:

Transparency: It means frankness, confrontation and disclosure, so that workers can speak openly about their views, face problems, and work to solve them in a one-team spirit away from fear, threat, and punishment [8].

Accountability: It means preparing to accept blame for failure or accepting praise and appreciation for success and achievement and includes an explanation and an explanation of why the failure occurred and what must be done to correct it [9].

Participation: It is a process carried out by stakeholders and beneficiaries by participating in the decision-making process and following up and monitoring the implementation of those decisions, which are always related to public services and development projects.

Rule of law: means the respect for and compliance with the law by all parts of society and taking the necessary measures to ensure its application to all without discrimination or favoritism.

Justice and equality: It means allowing, all workers to improve their lives and achieve and protect the well-being, to distribute opportunities, privileges, and workload among the employees of the organization fairly, and to equate each according to the requirements of his job and qualifications [10].

Efficiency and effectiveness: It means achieving the desired results in a way that satisfies the needs and desires of the relevant parties through working to optimize the available human, material and administrative resources.

\section{INSTITUTIONAL PERFORMANCE}

Institutional performance is the central axis around which the efforts of officials are concentrated, as it is how an organization can achieve its goals. In light of the growing changes taking place in the global arena, which resulted in increased competition and improved services, most public organizations are working to develop their institutional performance. That is why organizations are always striving to assess their capabilities and development to improve their business performance [11]. The opinions of researchers on the concept of institutional performance have multiplied, due to the different standards and measures used in its measurement, and the multiplicity of approaches in its study across its different levels [12]. Some see that institutional performance is the institution's ability to continue, survive, and survive[13]. Others see institutional performance as the interaction between behavior and achievement linked to results, which is the primary focus and topic of improvement and development in organizations [14].

Some view institutional performance as a set of complex interactions that take place between individuals and between the methods, materials, and equipment they use, as well as between these individuals and the culture and environment in which they operate [15].(Scott, 2003). Institutional 
performance is the ability of an organization to convert inputs into outputs through processes and benefit from feedback [16].(Shaw, et al., 2005). Institutional performance reflects practical behavior that leads to goals and a reflection of how an organization uses and exploits material and human resources in a way it makes them able to achieve their goals [17]. Institutional performance enhances an organization's ability to achieve organizational goals through the efficient and effective use of resources [18]. Various concepts seek to define institutional performance, including the concepts of efficiency and effectiveness [19].We conclude from the above that the institutional performance is the institution's ability to take advantage of its internal financial, organizational, human, and technological resources, and work to achieve interaction between these resources and the external environment of the institution in a manner that achieves its goals efficiently and effectively.

There are four dimensions through which institutional performance can be measured in what is known as a balanced scorecard, and a balanced scorecard can be defined as, a set of financial and non-financial metrics that provide the institution with a clear and comprehensive picture of performance, [20] and the dimensions of the scorecard can be reviewed Balanced as follows:

Financial dimension: This dimension indicates the institution's ability to carry out its work and achieve its goals in a manner consistent with the capabilities of its financial budget, through achieving efficiency and effectiveness of operating expenses.

Customers: This dimension indicates customer interest as a primary priority, as any organization, whether seeking for profit or not for profit (service), seeks to maintain a reputation and positive relationship with the public and achieve their satisfaction.

Internal operations: This dimension focuses on the internal operations and procedures in the organization and the level of services resulting from there, as well as the degree of speed in making decisions, the time to complete transactions, and the extent of dependence on modern electronic technologies at work.

Learning and growth: It means investment in human resources, operations, and work systems, and it can be said that this dimension determines how the organization can be able to change and improve continuously.

\section{LITERATURE REVIEW}

Pradhan [21]indicates the possibility of achieving a high level of economic growth and human development through improving the mechanism and level of good governance. Concerning the role of governance in increasing per capita income and improving social indicators in South Asian countries,[22] pointed out the importance of governance in increasing per capita income and stressed the importance of the role of international organizations in the area of finance and expertise to support governance.Kauzya [23] has indicated that African countries have achieved great successes in applying governance through a set of policies and strategies and that governance is activities for developing individuals with high levels of transparency, participation, responsibility, and justice. In addition, [24] stressed the need for quantitative and qualitative performance indicators for local government to achieve the goals set for local administration, and the study showed the need for performance management structures in which strategic planning and goal-building processes are evident. Furthermore, [25] conducted analytical studies of global trends in higher education management in European universities and a comparison of their application in Romanian universities, and he explained that Romanian universities need some improvements in the field of applying governance practices in the field of higher education. As for a [26] study, it was concluded that good management practices have an important and comprehensive impact on performance and that these practices must comply with the requirements of governance. The study of [27] also recommended developing governance practices to reduce challenges posed by the knowledge economy.

On the other hand,[28] concluded that good governance at the job level positively affects the level of employee satisfaction and communication process within the organization and improves the decisionmaking process and hence the overall performance of the organization. Katou and Budhwar [29] found a direct relationship between HRM practices and HRM outputs, as well as the impact of HRM practices on organizational performance. Chua et al. [30] concluded that there is a positive impact of empowering workers on institutional performance through developing financial performance and increasing customer 
satisfaction, as it was found that there was a positive effect of teamwork on institutional performance. Moreover, Cheng [31] stressed that the participation of non-profit organizations in governance has been negatively affected by the government's ability to provide public services, and called for the necessity of cooperation and participation between government and non-profit organizations in production and production. Providing public services.Regarding institutional performance, the study of [32] was found that patients under the Malcolm Baldrige system receive equal or better care from competitors while providing a better patient experience at the same time and that useful application of the Malcolm Drage system positively affects organizational performance. Franklin [33] concluded that there is a strong positive relationship between strategic planning and organizational performance and that this relationship is effectively reflected in customer service. Similarly, Katou and Budhwar [29] stressed the need for predefined management plans for business development, and that administrative policies, management development programs, and budget availability are among the most important local and federal factors that enhance their performance.

The study of Naikuni [34] found a positive relationship between all HRM practices and institutional performance that the most vital HRM practices affecting institutional performance are training and development, and that polarization was the least HRM practices affecting institutional performance. Singh et al. [35] They also found a link between the internal environment and organizational performance, and that the relationship between the external environment and organizational performance was weak. Furthermore, Hong et al. [36] concluded that implementing positive ERP systems depends on organizational capabilities and providing the organization with a higher level of institutional performance. By reviewing the previous literature, it is clear that most of it focuses on concepts of governance and institutional performance, and defining the role of each in achieving excellence for public and private institutions. It also contributed to defining the problem and designing the study tool. The literature differed in terms of the objective for each, and therefore the approach differed accordingly, which differs from the objective of the current study, which is to determine the impact of governance on institutional performance. This study differs from previous studies in the applied aspect; it is one of the few studies that examine the impact of governance on institutional performance in the northern border region, as well as determining the impact of each of the principles of governance on institutional performance.

\section{METHODOLOGY}

The study relied systematically on the descriptive analytical approach to build a conceptual basis for the concepts and variables of the study, which is governance and institutional performance and the study and analysis of data related to these variables.

\section{HYPOTHESES}

H1: There is no significant difference between the opinions of the three study groups (senior management - middle management - executive management) about the study variables (governance institutional performance) of the entity under study.

H2: There was no significant effect of the different governance principles on the overall institutional performance in the entity under study.

\section{STUDY TOOL}

In light of hypotheses, we developed a questionnaire consisting of 42 statements. The questionnaire was divided into two parts, as follows:

The first part aims at measuring governance (independent variable) using 25 phrases distributed across the different principles of governance, which are transparency in four phrases, accountability in four phrases, participation in six phrases, the rule of law in four phrases, justice and equality in three phrases, efficiency and effectiveness in four phrases. The second part consists of measuring the institutional performance (dependent variable) using 17 phrases distributed on the different dimensions of institutional performance: the financial dimension in four phrases, customers are three phrases, internal operations are 
five phrases, learning and growth are five phrases. The five-point Likert scale was used in the questionnaire, which was divided into five criteria ranging from (Strongly Agree, Agree, Neutral, Disagree, and Disagree strongly). The above five answers were given grades 5, 4, 3, 2, 1, respectively.

\section{STUDY POPULATION}

The study population consists of all officials and employees of the Secretariat of the Northern Borders Region in the Kingdom of Saudi Arabia, which account for 2465 members.

\section{STUDY SAMPLE}

In this study, we rely on selecting a sample that includes all officials and workers in the main center of the secretariat of the Northern Border region, who are 309 members. Questionnaires were distributed among study groups, and the retrieved and approved questionnaires were 238, with a response rate of 77.02 $\%$. Table 1 shows the Personal characteristics of the study sample.

Table 1: Personal characteristics of the study sample $(n=238)$

\begin{tabular}{|l|l|l|l|l|}
\hline \multicolumn{2}{|l|}{ Sample Distribution } & Frequency & Approved questionnaires & Percentage \\
\hline \multirow{3}{*}{ Gender } & Male & 264 & 204 & $77.27 \%$ \\
\cline { 2 - 5 } & Female & 45 & 34 & $75.56 \%$ \\
\hline \multirow{3}{*}{ Administrative level } & senior management & 38 & 28 & $73.68 \%$ \\
\cline { 2 - 5 } & middle management & 92 & 71 & $77.17 \%$ \\
\cline { 2 - 5 } & executive management & 179 & 139 & $77.65 \%$ \\
\hline \multicolumn{2}{|l}{ Total } & 309 & 238 & $77.02 \%$ \\
\hline
\end{tabular}

\section{STUDY MODEL}

Figure 1 illustrates the study model that includes study variables. Concerning the independent variable (governance) it is defined according to the principles issued by the United Nations Development Program [2]. Regarding the dependent variable (institutional performance) with its four dimensions, according to the balanced scorecard [20]. In order to serve the objectives of the study, the study model is represented in Figure 1.

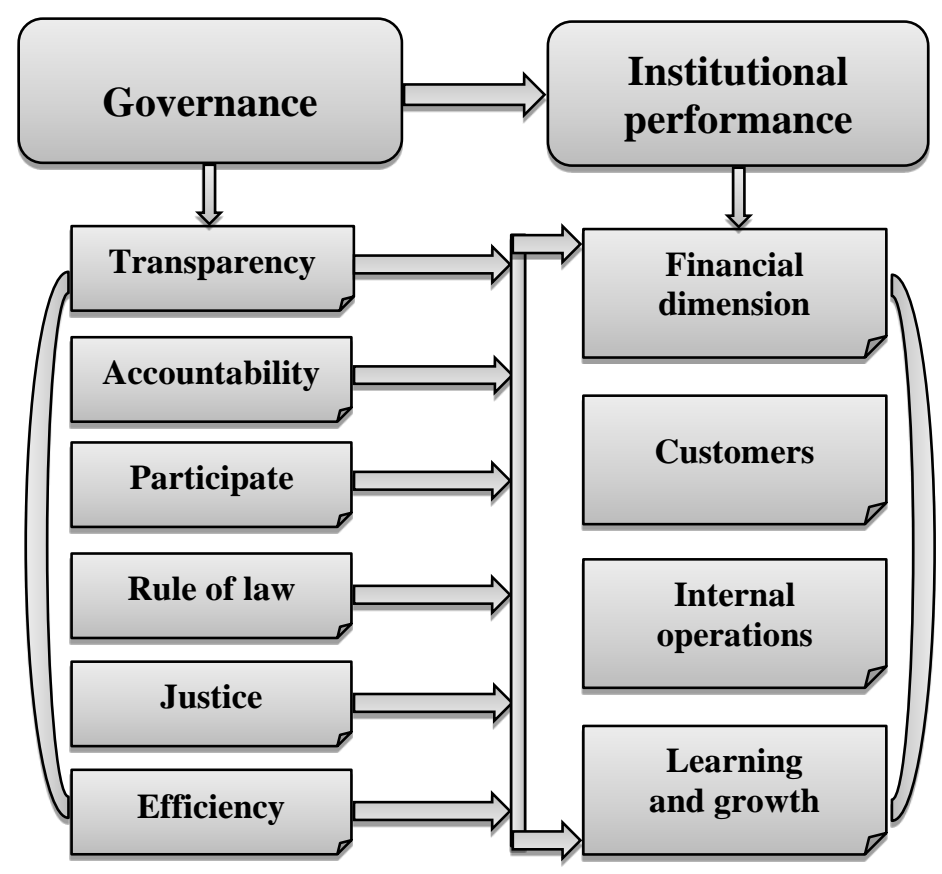

Fig. 1: Study model 


\section{RESULTS AND DISCUSSION}

\section{THE RELIABILITY COEFFICIENT OF CRONBACH'S ALPHA}

The Cronbach's Alpha reliability coefficient was calculated for the study tool (questionnaire). Table 2 shows that the reliability coefficient values are acceptable for all parts. The coefficient of reliability ranged between 0.711 for the fourth dimension of the dependent variable, learning and growth, and 0.908 for the third dimension of the independent variable, participation. The value of the validity coefficient ranged from 0.827 for the fourth dimension of the dependent variable, which is learning and growth, and 0.924 for the third dimension of the independent variable. From the above, we conclude that the data of the sample of the study has reasonable reliability, where the value of alpha exceeded $0.60 \%$ on all dimensions and parts, which indicates the stability of responses and the reliability of the results and dissemination of these results to the whole study population.

Table 2. Cronbach's alpha values

\begin{tabular}{|l|l|l|l|l|}
\hline Parts & Elements & No. of items & $\begin{array}{l}\text { Reliability Coefficient } \\
\text { (Alpha) }\end{array}$ & Self-validity coefficient \\
\hline Part One & Governance (X) & 25 & 0.894 & 0.913 \\
\hline First & Transparency (X1) & 4 & 0.868 & 0.906 \\
\hline Second & Accountability (X2) & 4 & 0.774 & 0.841 \\
\hline Third & Participate (X3) & 6 & 0.908 & 0.924 \\
\hline Fourth & Rule of law (X4) & 4 & 0.842 & 0.867 \\
\hline Fifth & Justice and equality (X5) & 3 & 0.796 & 0.852 \\
\hline Sixth & Efficiency and effectiveness (X6) & 4 & 0.731 & 0.832 \\
\hline Part Two & Institutional performance (Y) & 17 & 0.896 & 0.921 \\
\hline First & Financial dimension (Y1) & 4 & 0.774 & 0.854 \\
\hline Second & Customers (Y2) & 3 & 0.881 & 0.928 \\
\hline Third & Internal operations (Y3) & 5 & 0.849 & 0.898 \\
\hline Fourth & Learning and growth (Y4) & 5 & 0.711 & 0.827 \\
\hline
\end{tabular}

The Statistical Validity and Reliability Test of the Research Scale

\section{TESTING OF THE HYPOTHESES}

H1: There is no significant difference between the opinions of the three study groups (senior management - middle management - executive management) about the study variables (governance institutional performance) of the entity under study.

Table 3 shows descriptive statistics related to the study sample in the secretariat of the Northern Borders Region according to the administrative level about governance. Table 5 shows an increase in the average views of the study sample with its three administrative levels on governance practices. Senior management opinions came in the lead with an average of 4,011 and a standard deviation of 0.721 , followed by the middle management with an average of 3,834 and a standard deviation of 0.630 . Finally the executive management with an average of 3,652 and a standard deviation of 0.816 , It is clear from Table 5 the approval of the three study groups on governance practices. The views of senior and middle management were higher than the views of the executive management because both the senior and middle management bear a greater responsibility from the executive management in addition to the two departments are more convinced that the performance of the work is consistent with the correct scientific method For governance.

Table 3: The sample opinions on the principles of governance

\begin{tabular}{|l|l|l|}
\hline \multirow{2}{*}{ Classes of study } & Governance \\
\cline { 2 - 3 } & Mean & Standard Deviation \\
\hline Senior management & 4.011 & 0.721 \\
\hline Middle management & 3.834 & 0.630 \\
\hline Executive management & 3.652 & 0.816 \\
\hline
\end{tabular}


Table 4 shows descriptive statistics related to the study sample in the secretariat of the Northern Borders Region according to the administrative level about Institutional performance. Table 5 shows an increase in the average views of the study sample with its three administrative levels on Institutional performance. Senior management opinions came in the lead with an average of 4,042 and a standard deviation of 0.916 , followed by the middle management with an average of 3,814 and a standard deviation of 0.763. Finally, the executive management with an average of 3,713 and a standard deviation of 1.027, It is clear from Table 6 the approval of the three study groups on Institutional performance, and the views of senior and middle management were higher than the views of the executive management This is because both senior and middle management are more convinced than the executive management that the institutional performance is progressing as planned.

Table 4: Sample opinions on institutional performance

\begin{tabular}{|l|l|l|}
\hline \multirow{2}{*}{ Classes of study } & \multicolumn{2}{|l|}{ Institutional performance } \\
\cline { 2 - 3 } & Mean & Standard Deviation \\
\hline Senior management & 4.042 & 0.916 \\
\hline Middle management & 3.814 & 0.763 \\
\hline Executive management & 3.713 & 1.027 \\
\hline
\end{tabular}

To test a significant difference between the average opinions of study group members (senior management- middle management- executive management) regarding study variables, the Kruskal-Wallis test was used, which is a non-standard test that tests the difference between several averages).Table 5 shows the test results, which say that there is no significant difference between the views of faculty members on study variables, which is due to the administrative level and the level of importance 5\%. Moreover, the value P (Sig.) is greater than the significance level. The thing that there is no significant difference between the opinions of the three study groups (senior management - middle management executive management) about the study variables (Governance - Institutional performance).

From the above, the validity of the first hypothesis is apparent: "There is no significant difference between the opinions of the three study groups (senior management - middle management- executive management) about the study variables (governance - institutional performance) in the entity under study.

Table 5: Kruskal-Wallis test results by administrative level

\begin{tabular}{|l|l|l|l|}
\hline Variables & $\begin{array}{l}\text { Kruskal- } \\
\text { Wallis H }\end{array}$ & Sig. & Significance Interpretation \\
\hline Governance (X) & 2.624 & 0.658 & Not Significance \\
\hline Institutional performance (Y) & 3.943 & 0.490 & Not Significance \\
\hline
\end{tabular}

H2: There was no significant effect of the different governance principles on the overall institutional performance in the entity under study.

Table 6 shows the Pearson correlation coefficient between the principles of (total) governance and institutional performance (total). Table 6 shows a strong correlation between governance and institutional performance. The correlation coefficient is 0.632 , and the significance score is $1 \%$. Moreover, Table 6 also shows a strong positive correlation between each principle of governance and institutional performance in the entity under study. Correlation coefficients ranged between 0.459 as a minimum and represented the correlation between justice and equality and institutional performance and 0.774 as a maximum and represent the link between accountability and performance Institutional.

Table 6:Pearson correlations between the principles of governance and institutional performance

\begin{tabular}{|c|c|c|c|c|c|c|c|}
\hline \multirow{2}{*}{ Elements } & Transparency & Accountability & Participate & $\begin{array}{l}\text { Rule o } \\
\text { law }\end{array}$ & equality & \begin{tabular}{l|l|} 
and & Efficiency \\
& effectiveness
\end{tabular} & $\begin{array}{l}\text { and Institutional } \\
\text { performance }\end{array}$ \\
\hline & $\mathrm{X} 1$ & $\mathrm{X} 2$ & X3 & $\mathrm{X} 4$ & X5 & X6 & $\mathrm{Y}$ \\
\hline Transparency X1 & 1 & & & & & & \\
\hline Accountability X2 & $0.561^{* *}$ & 1 & & & & & \\
\hline Participate X3 & $0.451^{* *}$ & $0.414^{* *}$ & 1 & & & & \\
\hline Rule of law X4 & $0.622^{* *}$ & $0.510^{* *}$ & $0.511^{* *}$ & 1 & & & \\
\hline Justice and equality X5 & $0.581^{* *}$ & $0.623^{* *}$ & $0.619^{* *}$ & $0.659^{* *}$ & 1 & & \\
\hline \begin{tabular}{|ll} 
Efficiency & anc \\
effectiveness X6
\end{tabular} & $0.451^{* *}$ & $0.308^{* *}$ & $0.406^{* *}$ & $0.661^{* *}$ & $0.329^{* *}$ & 1 & \\
\hline $\begin{array}{l}\text { Institutional } \\
\text { performance Y }\end{array}$ & $0.618^{* * *}$ & $0.774^{* *}$ & $0.671^{* *}$ & $0.727^{* *}$ & $0.459^{* *}$ & $0.542^{* *}$ & 1 \\
\hline
\end{tabular}

Note: $* *$ denotes the statistical significance at the $1 \%$ level 
To define the relationship between governance and its various principles and institutional performance, a multiple regression method was used. Table 7 shows estimates of the multiple regression model for dependent variable regression (institutional performance) over the independent variable governing its various principles (transparency, accountability, participation, the rule of law, justice, equality, efficiency, and effectiveness), as shown in Table 7, the significance of the regression model estimated at $\mathrm{F}(374.458)$, and the value ( $\mathrm{sig}=0.000)$, as the significance of the regression coefficients and the significance of the constant term through the values of $t$ and the values (mark) of the significance level $5 \%$. It is also clear from the table that the indication of regression coefficients is positive, which indicates the effect of the principles of governance on the overall institutional performance. More interest in the principles of governance leads to the development of institutional performance in the Secretariat of the Northern Border Region. The value of the coefficient of determination was 0.662 , which indicates that governance with its various principles (independent variable) is explained by $66.2 \%$ of the changes that occur in institutional performance (dependent variable). The rest is due to other variables that are not included in the analysis model, in addition to the standard error. Looking at the (t-test) to test the morale of governance principles, we find that the most influential principles of governance on institutional performance were, respectively, accountability $\mathrm{x} 2$, the rule of law $\mathrm{x} 4$, participation $\mathrm{x} 3$, transparency $\mathrm{x} 1$, efficiency and effectiveness $x 6$, justice and equality $x 5$. This is what proves the incorrectness of the second hypothesis of the study and the validity of the alternative hypothesis, which states that "there is a significant effect of the principles of different governance on the overall institutional performance in the area under study". This finding is consistent with the findings of studies [37] [38] [39] [40] [41][42], and this result differed with [43].

Table 7: Multiple Regression Model for the Impact of Governance Principles on Institutional Performance

\begin{tabular}{|c|c|c|c|c|c|}
\hline \multirow{2}{*}{ R2 } & \multirow{2}{*}{$F($ sig. $)$} & \multicolumn{4}{|l|}{ Estimates } \\
\hline & & & $\mathrm{B}$ & $\mathrm{T}$ & Sig. \\
\hline \multirow{7}{*}{0.662} & \multirow{7}{*}{$\begin{array}{l}374.458 \\
(0.000)\end{array}$} & Constant & 1.578 & 13.547 & 0.000 \\
\hline & & Accountability X2 & 0.528 & 10.218 & 0.000 \\
\hline & & Rule of law X4 & 0.124 & 8.073 & 0.000 \\
\hline & & Participate X3 & 0.032 & 5.583 & 0.000 \\
\hline & & Transparency X1 & 0.361 & 3.694 & 0.000 \\
\hline & & Efficiency and effectiveness X6 & 0.044 & 3.218 & 0.000 \\
\hline & & Justice and equality X5 & 0.266 & 1.985 & 0.001 \\
\hline
\end{tabular}

\section{CONCLUSION}

Theoretical literature agreed on the vital role of governance in improving the performance of organizations in general, as well as on many other elements such as productivity, organizational loyalty, job satisfaction, and cognitive behavior.Therefore, most organizations seek to create the appropriate conditions to activate the practices and principles of governance in the belief in their role in achieving stability and growth at the institutional level. This study mainly focuses on identifying the impact of governance on institutional performance, as this study was carried out by applying it to the secretariat of the northern border region in the Kingdom of Saudi Arabia.

The results showed that the practices related to governance and institutional performance were accepted by the study sample, as it was found that there was an agreement between the opinions of the study groups on that. There is also a positive correlation between governance with its various principles and the overall institutional performance, where practices related to the principles of governance contribute significantly to developing institutional performance in its various dimensions in the area under study.

The study has a vital contribution in terms of understanding and determining the level of influence of each of the principles of governance on institutional performance, The impact of all principles of governance has appeared positively on institutional performance, but the degree of influence of each principle of governance has varied, The principle of accountability came as the most principles of governance that affect institutional performance, and the principle of justice and equality came as the least principle of governance that affects institutional performance. 
The study recommends the necessity of paying attention to deepening understanding and awareness of everything related to the principles and mechanisms of governance in public organizations through the continuous improvement of human resources capabilities and knowledge to deal with the principles of governance, with the need to work to provide an appropriate climate for their application and increase the level of positive impact on the various dimensions of institutional performance and confirm the study on the importance of increasing the level of cooperation between the government and the stakeholders in the development, the private sector and civil society concerning the governance system.

\section{REFERENCES}

[1] Pettai, V., \& Illing, E. (2004). Governance and good governance. Trames, 8(4): pp. 347-351.

[2] United Nations Development Peogramme (UNDP), (1997). Governance for Sustainable Human Development, a UNDP Policy Document, New York, p.3

[3] Humphreys, C., and Banerji, A. eds. (2003). Better governance for development in the Middle East and North Africa: enhancing inclusiveness and accountability. The World Bank.

[4] Asher, M. G. (2007). Reforming governance and regulation of urban cooperative banks in India. Journal of financial regulation and compliance, 15(1): pp. 20-29.

[5] Balasubramanian, N. (2011). Corporate Governance-By Robert AG Monks and Nell Minow. Corporate Governance: An International Review, 1(20): pp. 119-120.

[6] Osborne D., Gaebler T. (1992) Reinventing government: How the entrepreneurial spirit is transforming the public sector, New York: Addison-Wesley.

[7] Wang, L. (2010). Higher education governance and university autonomy in China. Globalisation, Societies and Education, 8(4), 477-495

[8] McCambridge, R. (2004). Underestimating the power of nonprofit governance. Nonprofit and Voluntary Sector Quarterly, 33(2): pp. 346-354.

[9] Gronlund, N. E. (1974). Determining accountability for classroom instruction. Macmillan Publishing Company.

[10] Michael, B. \& Gross, R. (2004), "Running business like a government in the new economy: lessons for organizational design and corporate governance", Corporate Governance, 4 (3): pp. 32-46.

[11] Day, G. S., \& Van den Bulte, C. (2002). Superiority in customer relationship management: Consequences for competitive advantage and performance. Marketing Science Institute, Report Summary No. 02-123: pp. 1-41.

[12] Hofer, C. W., \& Schendel, D. (1978). Strategy formulation: Analytical concepts. West Publ.

[13] Drucker, P. F. (1995). People and performance: The best of Peter Drucker on management. Routledge.

[14] Endres, G. M., \& Mancheno-Smoak, L. (2008). The Human Resource Craze: Human Performance Improvement and Employee Engagement. Organization Development Journal, 26(1): pp. 69-78.

[15] Scott, W. (2003). Performance improvement interventions: Their similarities and differences. The Journal for Quality and Participation, 26(1): pp. 26.

[16] Shaw, J. D., Gupta, N., \& Delery, J. E. 2005. Voluntary turnover and organizational performance. Academy of Management Journal, 48: $50-68$.

[17] Miller, K. D., \& Bromiley, P. (1990). Strategic risk and corporate performance: An analysis of alternative risk measures. Academy of Management journal, 33(4): pp. 756-779.

[18] Tayler, W. B. (2010). The balanced scorecard as a strategy-evaluation tool: The effects of implementation involvement and a causal-chain focus. The Accounting Review, 85(3): pp. 1095-1117.

[19] Peterson, W., Gijsbers, G., \& Wilks, M. (2003). An organizational performance assessment system for agricultural research organizations: concepts, methods, and procedures.

[20] Kaplan, R. S., \& Norton, D. P. (2005). The balanced scorecard: measures that drive performance. Harvard business review, 83(7): p. 172.

[21] Pradhan, R. P. (2011). Good governance and human development: evidence form Indian states. Journal of Social and Development Sciences, 1(1): pp. 1-8.

[22] Uddin, M. J., \& Joya, L. A. (2007). Development through good governance: Lessons for developing countries. Asian Affairs, 29(3): pp. 1-28

[23] Kauzya, J.M. (1998), Local Governance Capacity Building for Full Range Participation; Concepts, Frameworks and Experiences in African Countries. 
[24] Sansom, G. (2001). Towards Performance Management for Better Local Governance, Local Administration Research 15(1): pp. 197-216

[25] Brătianu, C., Reinhardt, Z., \& Almăsan, O. (2010). Practice models and public policies in the management and governance of higher education. Transylvanian Review of Administrative Sciences, 6(29): pp. 39-50

[26] Lokuwaduge, C. S. D. S., \& Armstrong, A. (2015). An evaluation of governance mechanisms as determinants of performance: A case study of Australian universities. Evaluation Journal of Australasia, 15(2): pp. 22-32.

[27] Beg, N., \& Ashok, A. (2015). Development and sustenance of efficient governance in universities An exploratory study. Abhinav International Journal of Research in Management \& Technology, 4(5): pp. 83-92.

[28] Jinarat, V., \& Quang, T. (2003). The impact of good governance on organization performance after the Asian crisis in Thailand. Asia Pacific Business Review, 10(1): pp. 21-42.

[29] Katou, A. A., \& Budhwar, P. S. (2010). Causal relationship between HRM policies and organisational performance: Evidence from the Greek manufacturing sector. European management journal, 28(1): pp. 25-39.

[30] Chua, G. S., Jusoh, M. S., Amlus, M. H., Abidin, R., \& Ibrahim, A. (2014). The relationship between employee empowerment, team work and recognition on company performance: An investigation in Malaysian manufacturing industry. Australian Journal of Basic and Applied Sciences, 8(12): pp. 7-17

[31] Cheng, Y. (2019). Exploring the role of nonprofits in public service provision: moving from coproduction to cogovernance. Public Administration Review, 79(2): pp. 203-214

[32] Schulingkamp, R. C., \& Latham, J. R. (2015). Healthcare performance excellence: A comparison of Baldrige award recipients and competitors. Quality Management Journal, 22(3): pp. 6-22.

[33] Franklin, P. W. (2011). Relationship between strategic planning and nonprofit organizational performance. Unpublished Ph. D. dissertation, Capella University: United States.

[34] Naikuni, D. M. N. (2017). Contribution of Strategic Human Resource Management Practices in Achieving Institutional Performance in Kenya: Narok County Government Perspective (Doctoral dissertation, COHRED, JKUAT).

[35] Singh, S., Darwish, T.K., Costa, A.C. and Anderson, N. (2012), "Measuring HRM and organisational performance: concepts, issues, and framework", Management Decision, 50 (4): pp. 651-667.

[36] Hong, P., Dobrzykowski, D., Park, Y. W., HassabElnaby, H. R., Hwang, W., \& Vonderembse, M. A. (2012). The impact of ERP implementation on organizational capabilities and firm performance. Benchmarking: An International Journal, 19(4/5): pp. 618-633.

[37] Shin, J. C. (2010). Impacts of performance-based accountability on institutional performance in the US. Higher Education, 60(1): pp. 47-68

[38] Alexander, F. K. (2000). The changing face of accountability: Monitoring and assessing institutional performance in higher education. The journal of higher education, 71(4): pp. 411-431.

[39] Han, Y. (2020). The impact of accountability deficit on agency performance: performanceaccountability regime. Public Management Review, 22(6): pp. 927-948.

[40] Alshaerb, I. M. A., Al-Hila, A. A., Al Shobaki, M. J., \& Abu Naser, S. S. (2017). Governance of Public Universities and Their Role in Promoting Partnership with Non-Governmental Institutions. International Journal of Engineering and Information Systems (IJEAIS), 1(9): pp. 214-238.

[41] Mersland, R., \& Strøm, R. Ø. (2009). Performance and governance in microfinance institutions. Journal of Banking \& Finance, 33(4): pp. 662-669

[42] Alzurqan, S. T., \& Al_Sufy, F. J. (2011). The effect of corporate governance on the performance of Jordanian industrial companies: An empirical study on Amman Stock Exchange. International Journal of Humanities and Social Science, 55-69.

[43] Hu, H., Islam, J., \& Sathye, M. (2015). Examining the relationship between corporate governance and bank performance in Bangladesh. South African Journal of Business Management, 46(4): pp. 43-52.

\section{Article history:}

Received 24 September 2020

Accepted 1 May 2021 